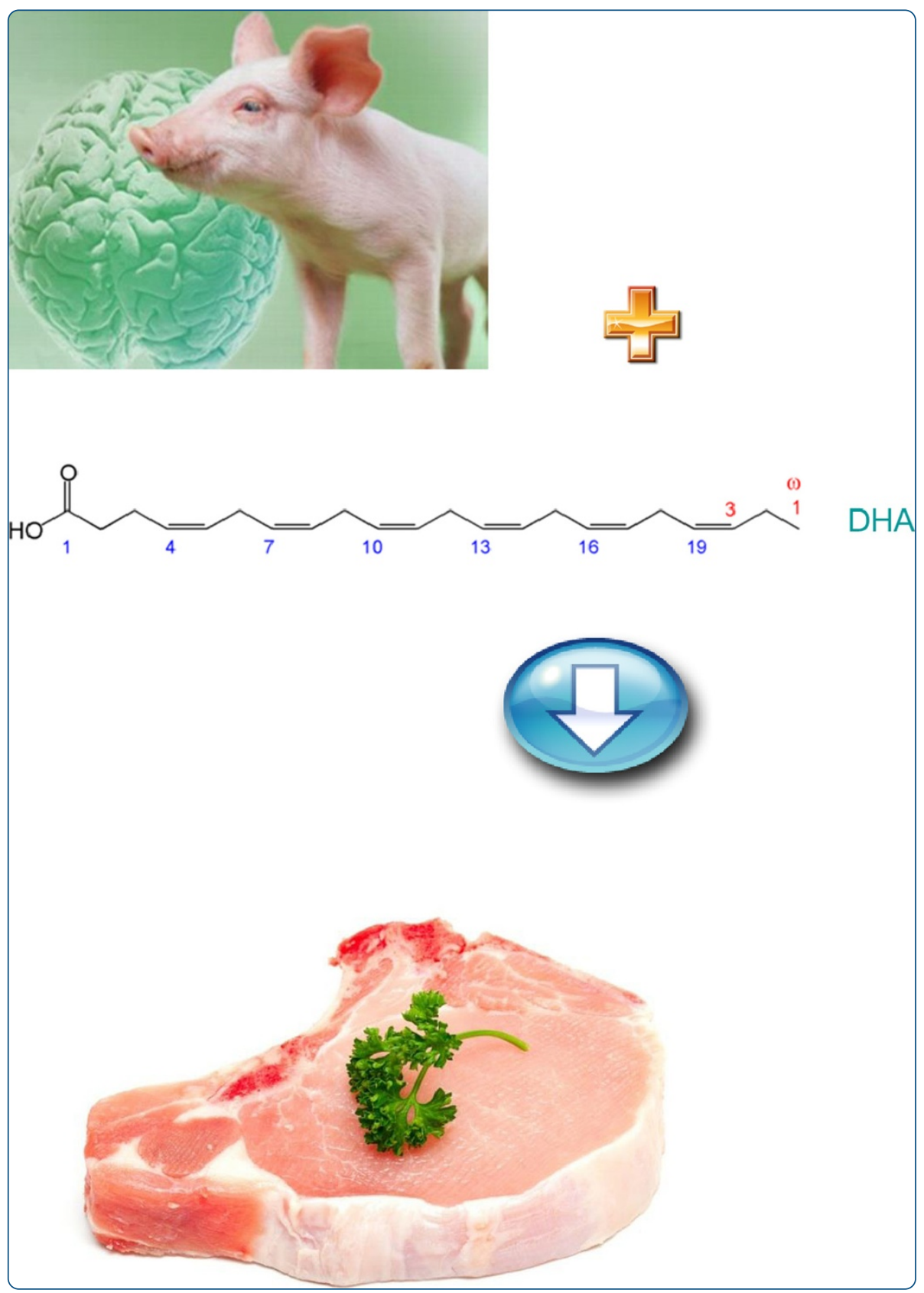

\title{
Fortification of pork loins with docosahexaenoic acid (DHA) and its effect on flavour
}

Meadus et al. 


\title{
Fortification of pork loins with docosahexaenoic acid (DHA) and its effect on flavour
}

\author{
William J Meadus*, Tyler D Turner, Michael ER Dugan, Jennifer L Aalhus, Pascale Duff, David Rolland, \\ Bethany Uttaro and Lorna L Gibson
}

\begin{abstract}
Pork is traditionally low in docosahexanoic acid (DHA, C22:6n-3) and deficient in omega-3 fats for a balanced human diet. DHA as triglycerides was commercially prepared from the microalgae Schizochytrium and injected into fresh pork loins. Treatments of a mixed brine control (CON), 3.1\% sunflower oil in mixed brine (SF) and a 3.1\% DHA oil in mixed brine (DHA) were injected into pork loins at $10 \mathrm{~mL} / 100 \mathrm{~g}$ and grilled at $205^{\circ} \mathrm{C}$. After cooking, the CON and SF pork loins contained 0.03 to $0.05 \mathrm{mg} \mathrm{DHA} / \mathrm{g}$ of pork and the DHA injected loins contained approximately $1.46 \mathrm{mg} \mathrm{DHA} / \mathrm{g}$. This also changed the fatty acid profile of omega-6: omega-3 from, 5 to 1 in the CON pork, to a ratio of 1.7 to 1 in DHA pork. The appearance, odor, oxidation rates and sensory taste, as judged by a trained panel, determined the DHA injected meat to be, 'slightly desirable' and gave lower 'off flavour' scores, relative to the CON and SF injected pork. Pork can be fortified with DHA oil to $146 \mathrm{mg} / 100 \mathrm{~g}$ serving, which would meet half the recommended daily omega 3 fatty acid requirements for adult humans and would be desirable in taste.
\end{abstract}

Keywords: Docosahexaenoic acid, Injection marinade, Pork, Sensory characteristics

\section{Background}

Pork is viewed as a lean healthy food, providing good nutrition; however, there are concerns about the quantity and types of fat it possesses. According to the USDA, a typical pork chop contains $11.3 \mathrm{~g}$ of fat/100 $\mathrm{g}$ of meat, of which $1.3 \mathrm{~g}$ is polyunsaturated fat and essentially no omega-3 fats [1]. Humans require the essential fatty acids omega-6 linoleic acid (C18:2n-6) and omega$3 \alpha$-linolenic acid (C18:3n-3) in their diet. Human adults are recommended to consume at least $1 \mathrm{~g} / \mathrm{d}$ of omega- 3 fat for proper cardiovascular health $[2,3]$. The long chain omega-3 fatty acid, docosahexaenoic acid (C22:6n-3), is particularly important, since it comprises $\sim 14 \%$ of the cerebral cortex $[4,5]$. To improve the omega-3 nutritional content of pork, researchers have fed plants such as, flax [6], soybeans and canola [7] which are high in $\alpha$-linolenic acid; however, $\alpha$-linolenic acid is only weakly converted to DHA [5]. Pork can be selectively enriched with DHA by feeding fish oils such as tuna [8] or by feeding microalgae biomass Schizochytricium [9]. However, there are problems with 'off' flavours and trimethylamine odors

\footnotetext{
* Correspondence: jon.meadus@agr.gc.ca

Agriculture and Agri-Food Canada, Lacombe Research Centre, 6000 C\&E Trail, Lacombe T4L 1 W1AB, Canada
}

caused by fish sources $[8,10,11]$ or with achieving adequate concentrations of expensive pure sources of dietary grade DHA. The option of directly injecting the DHA into the meat as a brine marinade, may overcome some of these issues.

Injecting water for moisture into pork has been in practice since 1960 [12]. The addition of a polyphosphate to a brine mixture further improves the juiciness, tenderness and flavour after cooking [13]; however, some discoloration has been noted. In addition to brine, injection of fats and oils [14] may improve the eating experience of pork. In North America, lean pork loins are averaging less than $2 \%$ intramuscular fat (IMF), the minimal IMF for consumer acceptance is $>3 \%$ [15]. The IMF adds flavour and juiciness and has a minor improvement on tenderness [16]. Beef injections with conjugated linoleic acid has recently been done to improve the nutrition but also to improve the eating quality experience of beef [17]. This study was done to improve the nutritional profile of pork by injecting lean pork loins with DHA oil and to assess consumer perceptions of eating quality and to examine if any off flavours would be generated by the DHA oil. 


\section{Methods \\ Chemicals}

Docosahexaenoic acid oil was supplied by Martek Bioscience Corporation (Boulder, CO, USA). Sunflower oil $100 \%$ was purchased from Compliments Company (Mississauga, ON, Canada). Sodium tripolyphoshate and salt was supplied by the Food Supplies Company (Winnipeg, Manitoba, Canada). The soy lecithin was from Solae, St. Louis, MO USA. Alpha tocopherol acetate was from Aquas Chem. Intl. (Torrance, CA, USA). Thiobarbituric acid, propyl gallate, ethylenediaminetetraacetic acid (EDTA), malonaldehyde, tetraethoxypropane, 1-hexanal, butanoic acid were purchased from SigmaAldrich Canada (Oakville, ON, Canada).

\section{Animals}

Animals used in this study were cared for and slaughtered, according to Canadian Council for Animal Care guidelines [18]. Barrows were selected from the Lacombe Research Centre f1 pig herd produced from Large White X Duroc mating. Pigs were given water ad libitum and fed a standard finisher diet comprised of $35 \%$ corn, $25 \%$ peas, $19 \%$ barley, $17 \%$ canola and $4 \%$ vitamin premix including $100 \mathrm{IU} / \mathrm{kg}$ of $\alpha$-tocopherol (vitamin E) and $0.5 \mathrm{mg} / \mathrm{kg}$ selenium [19]. The animals $(\mathrm{n}=20)$ were slaughtered at the Lacombe Research Centre abattoir at $120 \mathrm{~kg}$ after a $24 \mathrm{~h}$ feed withdraw but with full access to water. Carcasses were split and cooled for $24 \mathrm{~h}$ at $4^{\circ} \mathrm{C}$, then 24 carcass halves were selected and cut into primals, according to Canadian Meat Council guideline [20]. The $\sim 10 \mathrm{~kg}$ boneless loins were removed from both sides of the carcass, weighed, and distributed for treatment. Loins were evaluated and judge equal, based on visual colour and marbling scores [20].

\section{Injection treatment of pork loins}

Three treatments were allocated to the $24 \mathrm{~h}$ boneless loins ( $n=8$ loins/treatment). The treatments were an injection of $10 \mathrm{~mL} / 100 \mathrm{~g}$ loin (longissimus dorsi muscle) of mixed brine solution ( $\mathrm{CON}$ ) containing phosphate, sodium chloride, a $3.1 \%$ sunflower oil in the mixed brine solution (SF) or a 3.1\% DHA oil in mixed brine solution (DHA). The mixed brine consisted of, $4.8 \%$ sodium tripolyphosphate $\mathrm{Na}_{5} \mathrm{P}_{3} \mathrm{O}_{10}$ (BCCHEM, PQ, Canada), $4.8 \%$ sodium chloride, $0.01 \% \alpha$-tocopherol, and $0.15 \%$ precept 8140 powdered soy lecithin in distilled water. The SF oil consisted of the control brine mixed with $3.1 \%$ of mid oleic grade sunflower oil (Compliments, ON, Canada). The DHA oil consisted of the control brine mixed with $3.1 \%$ of DHA-S oil (Martek Bioscience Corp, Boulder, CO, USA). DHA-S oil was comprised of $35 \%$ docosahexaenoic acid extracted from microalgae mixed with $65 \%$ high oleic sunflower oil, $0.02 \% \alpha$ - tocopherol and $0.01 \%$ soy lecithin.
The injection of pork loins with $3.1 \%$ DHA or $3.1 \%$ sunflower oil in a tripolyphosphate brine solution would add approximately $0.31 \mathrm{~mL}$ of oil/100 $\mathrm{g}$ of pork. The brine mixtures were injected using $4 \mathrm{~mm}$ needles spaced $2.8 \mathrm{~cm}$ in an Inject Star BI-72 unit (J Redmond \& Sons, Northampton, UK), set at 2 bar and 56 strokes/min. After injection, the loins were allowed to equilibrate for $18 \mathrm{~h}$ at $2^{\circ} \mathrm{C}$ and then cut into 1 inch chops from the center, yielding 8-10 chops/loin, and 8 loins/treatment. The fluid loss was not measured at cutting. The chops from the three treatment groups, were packaged individually in polystyrene trays on dri-loc pads (UZ Soaker Ultra Zap Pads, Paper Pak Industries Washington, GA, USA), overwrapped with oxygen permeable film $\left(8,000 \mathrm{~mL} / \mathrm{m}^{2} / 24 \mathrm{~h}\right.$ vitafilm choice wrap (Goodyear Canada Inc, Toronto, ON, Canada) and stored for an additional $24 \mathrm{~h}$ at $+4^{\circ} \mathrm{C}$. Day 1 raw chops (approximately $66 \mathrm{~h}$ post mortem) were selected (2/loin/treatment) for evaluation by trained panellists for visual colour, striping caused by the injections and odours and measured for color and thiobarbituric acid (TBARS) and again after $3 \mathrm{~d}$, under refrigeration at $2^{\circ} \mathrm{C}$, the maximum reasonable limit for retail display [21,22]. A portion of the chops from each of the three treatments were sealed ( $n=12$ /treatment) immediately after cutting, in vacuum packages (Multivac AGW; Multivac Inc., Kansas City, $\mathrm{MO}, \mathrm{USA}$ ) and stored in a $-20^{\circ} \mathrm{C}$ freezer for the FAME analysis.

\section{Fatty acid analysis (FAME) of oil and raw pork loins}

Fatty acid methyl esters (FAME) extracts were isolated from the DHA and SF oils (Table 1). FAME extracts were also isolated (4/treatment) from CON, SF and DHA thawed raw chops and then the same chops were cooked at $205^{\circ} \mathrm{C}$ to an internal temperature of $71^{\circ} \mathrm{C}$ and then resampled. The samples were prepared according to the one-step extraction trans-esterification procedure [23]. Thawed raw and cooked pork loins (1 g) were pureed by blending with a Blixer 3, RoboCoupe (Ridgeland, MS,USA) food processor in $10 \mathrm{~mL}$ of $2: 1$ chloroform/ methanol and passing a through a $70 \mu \mathrm{mol} / \mathrm{L}$ glass filter. The FAME were extracted from the filtrate in $3 \mathrm{~mL}$ of hexane and then dried over sodium sulfate. Extracted lipids were methylated according to [24]. FAME was recovered in hexane prior to gas chromatography injection. FAME were analyzed using a Varian 3800GC (Varian, Walnut Creek, CA, USA) equipped with a Varian 8400 auto-sampler and a $30 \mathrm{~m}$ SP2340 capillary column (Supelco, Bellefonte, PA) with flame ionization detection. The injector and FID detector were set $250^{\circ} \mathrm{C}$ and gas flow at a constant 15 psi. Chromatograms were integrated using Varian Star Chromatography Workstation software. Peaks were identified using a GC reference standard GLC463 from Nu-Check-Prep, Elysian, 
Table 1 Fatty acid methyl ester profile of the DHA oil and Sunflower oil preparations

\begin{tabular}{|c|c|c|}
\hline FAME, (mg/g) & DHA oil, $(\mathrm{mg} / \mathrm{g})$ & Sunflower oil, $(\mathrm{mg} / \mathrm{g})$ \\
\hline C14:0 & 68.41 & 0.40 \\
\hline C16:0 & 166.37 & 39.66 \\
\hline C16:1cis9 & 2.62 & 0.61 \\
\hline C18:0 & 7.08 & 33.00 \\
\hline C18:1cis9 & 99.76 & 565.21 \\
\hline C18:1cis11 & 1.60 & 4.41 \\
\hline C18:2n-6 & 8.49 & 273.12 \\
\hline C18:3n-6 & 2.39 & 2.55 \\
\hline C18:3n-3 & 0.55 & 1.63 \\
\hline C20:1cis11 & 0.27 & 1.96 \\
\hline$C 20: 2 n-6$ & 1.81 & 8.40 \\
\hline$C 20: 3 n-6$ & 3.12 & 0.00 \\
\hline$C 20: 4 n-6$ & 2.99 & 0.00 \\
\hline$C 20: 5 n-3$ & 8.47 & 0.00 \\
\hline$C 22: 5 n-6$ & 146.20 & 0.00 \\
\hline$C 22: 5 n-3$ & 4.75 & 0.00 \\
\hline$C 22: 6 n-3$ & 394.15 & 0.00 \\
\hline Total FAME mg/g & 949.50 & 935.85 \\
\hline lodine Index ${ }^{1}$ & 271.36 & 110.43 \\
\hline
\end{tabular}

${ }^{1}$ Estimated iodine index calculated by the $\%$ of fatty acid with the sample multiplied by the iodine value of the fatty acid.

MN, USA). The iodine value of the fatty acids was calculated by multiplying the percentage of each fatty acid (Tables 1 \& 2) contained in the sample by the Iodine number of the fatty acids [25].

\section{Colour measurements}

The colour of each loin treatment section was measured using a Minolta CM2002 color meter (Minolta Canada Inc., ON, Canada). Chops were cut from the injected treated loin and allowed to oxygenate at $4^{\circ} \mathrm{C}$ for $20 \mathrm{~min}$ before taking the colour measurements directly from the meat surface. The CIE L*, a*, b* colour coordinates were recorded along with Chroma and hue values and illuminated using a Minolta CR-300 color meter on the raw injected chops at days 0,1 and 3 according to the manufacturers specification (Konica Minolta, Ramsay, NJ, USA).

\section{Thiobarbituric Acid Reactive Substances (TBARS)}

The free meat juice purge $(1 \mathrm{~mL})$ was collected from the drip trays ( $n=8 /$ treatment) of the raw $1 d$ and $3 d$, injected loin chops and then the chops were diced into $1 \mathrm{~g}$ cubes and blended with an Ultra Turax in $10 \mathrm{~mL}$ of extraction solution: trichloroacetic acid (75 g of TCA/L in water), propyl gallate $(1 \mathrm{~g} / \mathrm{L})$ and EDTA $(1 \mathrm{~g} / \mathrm{L})$. The extraction solution was filtered through a Whatman no. 42 filter then $2.5 \mathrm{~mL}$ of the filtered extract was mixed with $2.5 \mathrm{~mL}$ of thiobarbituric acid (TBA) $(2.88 \mathrm{~g} / \mathrm{L})$ and heated to $94^{\circ} \mathrm{C}$ for $40 \mathrm{~min}$. in closed glass vials. The samples were immediately cooled, and the absorbance was measured at $531 \mathrm{~nm}$. TBARS values were determined relative to a standard curve of malonaldehyde generated with $1 \mathrm{~g} / \mathrm{L}$ of tetraethoxypropane and $20 \mathrm{mmol} / \mathrm{L}$ to $90 \mathrm{mM}$ TBA solution [26].

\section{Sensory and odours evaluation of raw loin chops}

Panellist $(n=8)$ were informed, selected and trained, according to the American Meat Science Associations guidelines [27]. The panellist were asked evaluate the visual display of the $0 \mathrm{~d}$ and $3 \mathrm{~d}$ raw loin chops and give rating based on a 8-point hedonic scale for: overall retail appearance $(8=$ extremely desirable to $1=$ extremely undesirable) and descriptive scales for lean muscle color ( 1 = pale pink/grey and white to $6=$ dark purplish red), colour of striping ( $1=$ none to $7=$ yellow/brown), $\%$ striping $(1=$ none to $7=100 \%)$, spoilage colour $(1=$ none to 7 = brown), $\%$ surface spoilage $(1=$ none to $7=100 \%)$, and visual marbling score ( $1=$ devoid to $6=$ abundant $)$.

Odour rating was completed using a 4-point descriptive scale for Off odor intensity $(4=$ prevalent to $1=$ no off odours) a 5-point hedonic scale for odour acceptability ( 5 = unacceptable to 1 =acceptable), and a 9-point descriptive classification for Off odours $(9=$ other, $8=$ unidentified, $7=$ fishy, $6=\mathrm{rancid} /$ painty, $5=$ stale $/$ cardboard, 4 = piggy/barn like, $3=$ metallic, $2=$ off $/$ sour, $1=$ none). The panellist were also asked to rate the 3 brine mixtures.

\section{Sensory and odours evaluation of cooked loin chops}

Assessment of cooked chops was performed on $1 \mathrm{~d}$ loins, $24 \mathrm{~h}$ after brine injection and approximately $66 \mathrm{~h}$ post mortem. Each treated loin was weighed after removal from the vacuum pack and the percentage cooking loss was calculated based on the weight, before and after cooking. The injected loin chops, 8/treatment, were sliced into 1 inch chops and then cooked on a preheated Garland electric grill ED-30B at $205^{\circ} \mathrm{C}$. The chops internal temperature was monitored every $5 \mathrm{~s}$ with a type $\mathrm{T}$ thermo-coupled temperature probes until the internal temperature reached $71^{\circ} \mathrm{C}$. The cooked chops were allowed to cool for $3 \mathrm{~min}$ then trimmed of all outside edges and fat. Chops were cut into $1.3 \mathrm{~cm}$ cubes avoiding connective tissue and placed into $250 \mathrm{~mL}$ glass jars pre-warmed at $68^{\circ} \mathrm{C}$. The samples were served to the panellist under 180-lux light in well ventilated partitioned booths. Panellist cleaned their palates between each sample with unsalted crackers and filtered water.

The panellist were asked to rate the samples on 9-point descriptive scale for initial and overall tenderness $(9=$ extremely tender to $1=$ extremely tough), initial and sustained juiciness $(9=$ extremely juicy to $1=$ 
Table 2 Fatty acid methyl esters profile of the raw and cooked injected pork loins between Control brine (CON), Sunflower (SF) and DHA treatments

\begin{tabular}{|c|c|c|c|c|c|c|c|c|c|}
\hline \multirow{2}{*}{$\begin{array}{l}\text { FAME } \\
\text { mg/g wet tissue }\end{array}$} & \multicolumn{3}{|c|}{ Raw } & \multicolumn{4}{|c|}{ Cooked } & \multicolumn{2}{|c|}{$P$ value } \\
\hline & CON & SF & DHA & CON & SF & DHA & SEM & Treatment & Cooking \\
\hline C14:0 & $0.62^{a}$ & $1.24^{\mathrm{b}}$ & $1.27^{\mathrm{b}}$ & $0.55^{\mathrm{a}}$ & $1.44^{c}$ & $1.68^{c}$ & 0.130 & 0.005 & 0.004 \\
\hline $\mathrm{C} 16: 0$ & $10.90^{\mathrm{a}}$ & $22.28^{c}$ & $18.08^{b}$ & $10.54^{\mathrm{a}}$ & $26.65^{c}$ & $24.64^{c}$ & 1.524 & 0.001 & 0.001 \\
\hline C16:1cis9 & $1.16^{\mathrm{a}}$ & $2.12^{\mathrm{b}}$ & $1.93^{\mathrm{b}}$ & $1.11^{\mathrm{a}}$ & $2.60^{c}$ & $2.70^{c}$ & 0.164 & 0.002 & 0.002 \\
\hline C18:0 & $5.68^{\mathrm{a}}$ & $12.26^{\mathrm{c}}$ & $8.87^{\mathrm{b}}$ & $5.74^{\mathrm{a}}$ & $14.78^{d}$ & $12.09^{c}$ & 0.833 & 0.001 & 0.001 \\
\hline C18:1cis9 & $15.96^{\mathrm{a}}$ & $32.87^{c}$ & $24.59^{b}$ & $15.29^{\mathrm{a}}$ & $40.42^{c}$ & $33.79^{c}$ & 2.002 & 0.001 & 0.001 \\
\hline C18:1cis11 & $2.42^{\mathrm{a}}$ & $5.28^{b}$ & $3.92^{\mathrm{a}}$ & $2.13^{a}$ & $5.61^{b}$ & $4.95^{\mathrm{b}}$ & 0.335 & 0.001 & 0.177 \\
\hline C18:2n-6 & $3.05^{\mathrm{a}}$ & $5.47^{\mathrm{b}}$ & $4.26^{\mathrm{b}}$ & $3.05^{\mathrm{a}}$ & $6.64^{c}$ & $5.14^{\mathrm{b}}$ & 0.414 & 0.006 & 0.001 \\
\hline C18:3n-3 & $0.40^{\mathrm{a}}$ & $0.77^{\mathrm{b}}$ & $0.69^{b}$ & $0.32^{\mathrm{a}}$ & $0.87^{b}$ & $0.76^{\mathrm{b}}$ & 0.089 & 0.022 & 0.296 \\
\hline C18:3n-6 & $0.09^{\mathrm{a}}$ & $0.23^{\mathrm{b}}$ & $0.16^{\mathrm{b}}$ & $0.09^{\mathrm{a}}$ & $0.28^{\mathrm{b}}$ & $0.20^{\mathrm{b}}$ & 0.021 & 0.003 & 0.005 \\
\hline C20:1cis11 & $0.41^{\mathrm{a}}$ & $0.96^{\mathrm{b}}$ & $0.62^{\mathrm{b}}$ & $0.37^{\mathrm{a}}$ & $1.16^{\mathrm{c}}$ & $0.83^{b}$ & 0.075 & 0.002 & 0.004 \\
\hline$C 20: 2 n-6$ & $0.08^{\mathrm{a}}$ & $0.16^{c}$ & $0.12^{\mathrm{b}}$ & $0.07^{\mathrm{a}}$ & $0.21^{d}$ & $0.15^{c}$ & 0.016 & 0.007 & 0.023 \\
\hline$C 20: 3 n-6$ & 0.06 & 0.08 & 0.07 & 0.05 & 0.10 & 0.10 & 0.009 & 0.018 & 0.258 \\
\hline$C 20: 3 n-3$ & 0.03 & 0.06 & 0.05 & 0.03 & 0.07 & 0.06 & 0.008 & 0.062 & 0.102 \\
\hline C20:4n-6 & $0.28^{\mathrm{a}}$ & $0.34^{b}$ & $0.31^{b}$ & $0.33^{\mathrm{b}}$ & $0.45^{c}$ & $0.37^{\mathrm{b}}$ & 0.022 & 0.057 & 0.001 \\
\hline C20:5n-3 & 0.04 & 0.04 & 0.07 & 0.06 & 0.07 & 0.08 & 0.005 & 0.016 & 0.002 \\
\hline C22:0 & 0.01 & 0.03 & 0.02 & 0.01 & 0.02 & 0.02 & 0.003 & 0.009 & 0.073 \\
\hline$C 22: 5 n-6$ & $0.00^{\mathrm{a}}$ & $0.00^{\mathrm{a}}$ & $0.44^{b}$ & $0.01^{\mathrm{a}}$ & $0.00^{\mathrm{a}}$ & $0.54^{\mathrm{b}}$ & 0.025 & 0.001 & 0.108 \\
\hline$C 22: 5 n-3$ & 0.10 & 0.15 & 0.13 & 0.12 & 0.21 & 0.18 & 0.016 & 0.037 & 0.002 \\
\hline$C 22: 6 n-3$ & $0.02^{\mathrm{a}}$ & $0.04^{\mathrm{a}}$ & $1.16^{\mathrm{b}}$ & $0.03^{\mathrm{a}}$ & $0.05^{\mathrm{a}}$ & $1.46^{\mathrm{b}}$ & 0.068 & 0.000 & 0.075 \\
\hline $\mathrm{SFA}^{1}$ & $17.30^{\mathrm{a}}$ & $36.05^{c}$ & $28.41^{b}$ & $16.93^{\mathrm{a}}$ & $43.17^{c}$ & $38.63^{c}$ & 2.510 & 0.001 & 0.001 \\
\hline MUFA $^{2}$ & $19.95^{\mathrm{a}}$ & $41.23^{c}$ & $31.06^{c}$ & $18.90^{\mathrm{a}}$ & $49.78^{c}$ & $42.28^{c}$ & 2.576 & 0.001 & 0.001 \\
\hline PUFA $^{3}$ & $4.07^{\mathrm{a}}$ & $7.10^{\mathrm{b}}$ & $7.30^{\mathrm{b}}$ & $4.06^{\mathrm{a}}$ & $8.67^{c}$ & $8.83^{c}$ & 0.673 & 0.004 & 0.000 \\
\hline Total FAME & $41.32^{\mathrm{a}}$ & $84.38^{c}$ & $66.76^{\mathrm{b}}$ & $39.88^{a}$ & $101.62^{c}$ & $89.73^{c}$ & 1.920 & 0.002 & 0.001 \\
\hline lodine Index ${ }^{4}$ & $27.15^{\mathrm{a}}$ & $53.09^{b}$ & $46.65^{b}$ & $26.32^{\mathrm{a}}$ & $64.48^{c}$ & $60.95^{c}$ & 3.184 & 0.001 & 0.001 \\
\hline
\end{tabular}

abcd Means within rows with unique superscript, differ significantly $(P>0.05)$. SEM; standard error of means, within row.

'SFA; saturated fatty acids, with no double bonds.

${ }^{2}$ MUFA; monounsaturated fatty acids, with one double bond.

${ }^{3}$ PUFA; polyunsaturated fatty acids, with two or more double bonds.

${ }^{4}$ Estimated iodine index calculated by the\% of fatty acid with the sample multiplied by the iodine value of the fatty acid.

extremely dry), and salt intensity $(1=$ no salt to $10=$ extremely salty). Flavour desirability and overall palatability were rated on a 9-point hedonic scale $(1=$ not desirable to $9=$ extremely desirable). Off flavour intensity was rated on a 9-point scale $(9=$ extremely intense to $1=$ bland) and if off flavours were present, the panellist were asked to identify the most predominant descriptive classification for 'off odours' $(9=$ other, $8=$ unidentified, $7=$ fishy, $6=\mathrm{rancid} /$ painty, $5=$ stale $/$ cardboard, $4=$ piggy $/$ barn like, $3=$ metallic, $2=$ off $/$ sour, $1=$ none).

\section{Statistical analysis}

For all meat treatment group variables, least square means were generated and were tested for significance $(P<0.05)$ within GLM and ANOVA. The lipid profiles were analyzed using the MIXED procedure and signifi- cance was determined using the DIFF option and Duncan's test to identify differences between the groups means, CON, SF, and DHA and by raw and cooked treatment effect [28]. The statistical model included the treatment effect at $1 \mathrm{~d}$ or $3 \mathrm{~d}$ interaction. An ordinate scale was used for the panellist evaluations of the sensory measures using Friedman test and the nominal scale was used for the biochemical measurement values, using Tukey's HSD test.

\section{Results and discussion}

\section{Pork fatty acid content}

The injected loin treatments were primarily performed to determine if the DHA oil could be added at a concentration of $1 \mathrm{mg} / \mathrm{g}$ of fresh pork, without adversely affecting aroma or taste. Regular pork loins from pigs fed a standard finisher diet of, corn, barley, peas, and 
canola, would have $\sim 0.5 \mathrm{mg}$ of omega-3 FAME/g of meat and only $\sim 0.02 \mathrm{mg}$ of DHA FAME/g of meat [1]. Injection of the $3.1 \%$ DHA brine mixture at $10 \mathrm{~mL} /$ $100 \mathrm{~g}$ into the boneless meat, increased the DHA (C22:6n-3) content 50-fold, to an estimated concentration of $1.05 \mathrm{mg} / \mathrm{g}$ of pork. This changed the fatty acid profile of omega-6: omega-3 from, 5 to 1 in the CON pork, to a ratio of 1.7 to 1 in DHA pork. The actual concentration in the loin chops was $1.16 \mathrm{mg} / \mathrm{g}$ of raw pork (Table 2). In a previous study, $1.22 \mathrm{mg}$ DHA/g of raw bacon was achieved after feeding pigs, a diet containing $0.11 \%$ DHA for $25 \mathrm{~d}$-the equivalent of approximately $825 \mathrm{~g}$ DHA [29]. This trial achieved the $1.16 \mathrm{mg} \mathrm{DHA} / \mathrm{g}$ level in a $10 \mathrm{~kg}$ loin, by injecting approximately $3.1 \%$ DHA, equivalent to approximately $32 \mathrm{~g} \mathrm{DHA} / 10 \mathrm{~kg}$ loin. The retention of DHA was higher after cooking at $1.46 \mathrm{mg} / \mathrm{g}$ of cooked pork. This increase was probably due to water loss evaporation by grill cooking (Table 2). The average cooking loss for all three treatments was $21.5 \pm 3.04 \%$. Conservatively, this would adjust the estimated level of DHA to approximately $0.82 \mathrm{mg} / \mathrm{g}$ of pork, if the oil was retained evenly but usually, free fatty acid content is increased by cooking [17]. The amount of 18:1cis9 and 18:2n-6 was also significantly increased in the SF and DHA treatments (Table 1) but the final concentration of $18: 1$ cis 9 and 18:2n-6 was increased less than 2-fold in the actual raw and cooked pork (Table 2).

\section{Colour measurements}

Soy lecithin was added to the mixture because it was needed to assist the emulsion of the sunflower oil and DHA oil. The SF and DHA oil mixtures would separate into their respective phases, if left undisturbed. In the CON mixture, the addition of the soy lecithin will impart a slightly nutty aroma [30]. The vitamin E ( $\alpha$-tocopherol) was added to help maintain oxidative stability of the oil injection mixture and was considered as odourless and remained odourless after $6 \mathrm{~d}$, as judged while training the sensory panel. The addition of vitamin E to the injected chops was expected to help prevent rancid odours and flavours [31]. The brine mixture contained $0.01 \% \quad \alpha$ - tocopherol, which would inject approximately $0.001 \%$ into the loins. The brine's main ingredients were $4.8 \%$ sodium tripolyphosphate and $4.8 \%$ sodium chloride and were also determined to be odourless by the sensory panel (data not shown). Injection of a brine mixture increases tenderness and juiciness and might add some saltiness to the flavour while reducing the intensity of the pork flavour [32]. There were no difference in the behaviour of the SF or DHA oil emulsions, both oil preparations began to separate into the aqueous and oil phases in approximately $4 \mathrm{~h}$ after mixing and therefore needed constant stirring at $200 \mathrm{rpm}$ prior to injection. The injection mixture was prepared for the experiment within $2 \mathrm{~h}$ before use. The colour of the oil preparations were also similar and were lightly brown, caused by the soy lecithin. There was no difference in the subjective colour of the injected loin between the CON group containing no oil and treatment groups containing SF or DHA oils, as assessed by the panellists. No difference was detected in the 3 treatments when chops were pooled according to the 12 individual animals. The panellists also did not detect any difference in the retail display, marbling, or striping between the treatment groups (Table 3). However, in the

Table 3 Panellist assessment of raw loin chops for retail display, visual marbling, color, striping, and odours between injection treatments

\begin{tabular}{|c|c|c|c|c|c|c|c|}
\hline Day 1 & Retail display & Marbling & Color & Injection stripes & Visual discoloration & Off odours & Odour unacceptability \\
\hline $\mathrm{CON}$ & $3.93^{\mathrm{a}}$ & 2.38 & 3.91 & $3.09^{a}$ & 1.01 & 1.23 & $2.13^{a}$ \\
\hline SF & $4.02^{a}$ & 2.91 & 3.45 & $3.25^{\mathrm{a}}$ & 1.02 & 1.13 & $1.48^{\mathrm{a}}$ \\
\hline $\mathrm{DHA}$ & $3.80^{\mathrm{a}}$ & 2.43 & 3.57 & $3.05^{\mathrm{a}}$ & 1.02 & 1.18 & $1.80^{\mathrm{a}}$ \\
\hline SEM & 0.834 & 0.049 & 0.162 & 0.867 & 0.909 & 0.364 & 0.404 \\
\hline \multicolumn{8}{|l|}{ Day 3} \\
\hline $\mathrm{CON}$ & $2.57^{b}$ & 2.55 & 3.80 & $4.54^{b}$ & 1.07 & 1.25 & $2.09^{a}$ \\
\hline SF & $2.57^{b}$ & 3.02 & 3.52 & $4.28^{b}$ & 1.04 & 1.34 & $2.46^{b}$ \\
\hline $\mathrm{DHA}$ & $2.48^{b}$ & 2.69 & 3.52 & $4.23^{b}$ & 1.21 & 1.23 & $2.30^{b}$ \\
\hline SEM & 0.926 & 0.149 & 0.311 & 0.676 & 0.287 & 0.359 & 0.677 \\
\hline
\end{tabular}

${ }^{\mathrm{abc}}$ Means within column with unique superscript differ significantly $(P<0.05)$. SEM; standard error of the mean. Retail display ( $8=$ extremely desirable to $1=$ extremely undesirable).

Marbling ( $6=$ abundant to $1=$ devoid).

Color $(6=$ dark purple to $1=$ white).

Injection stripes ( $7=100 \%$ to $1=$ none).

Visual discoloration ( $7=$ brown to $1=$ none).

Off odours $(4=$ prevalent to $1=$ none).

Odour acceptability ( $5=$ unacceptable to $1=$ acceptable). 
Table 4 The effect of injection treatments on raw loin chops $(n=24)$ for TBARS estimated oxidation and Colour meter measurements L*, a*, b*, Chroma

\begin{tabular}{|c|c|c|c|c|c|c|}
\hline Day 1 & Oxidation in purge(TBARS) ${ }^{1}$ & Oxidation in meat (TBARS) ${ }^{1}$ & $\mathrm{~L}^{*}$ (lightness) & $a^{*}$ (redness) & $b^{*}$ (yellowness) & Chroma \\
\hline CON & $0.01^{\mathrm{a}}$ & 0.011 & 47.47 & $3.67^{\mathrm{a}}$ & $7.25^{\mathrm{a}}$ & $8.19^{a}$ \\
\hline SF & $0.01^{\mathrm{a}}$ & 0.010 & 49.83 & $3.76^{\mathrm{a}}$ & $8.17^{\mathrm{a}}$ & $9.05^{\mathrm{a}}$ \\
\hline $\mathrm{DHA}$ & $0.01^{\mathrm{a}}$ & 0.009 & 48.25 & $3.48^{\mathrm{a}}$ & $7.38^{\mathrm{a}}$ & $8.20^{\mathrm{a}}$ \\
\hline SEM & 0.178 & 0.501 & 0.137 & 0.862 & 0.126 & 0.254 \\
\hline \multicolumn{7}{|l|}{ Day 3} \\
\hline CON & $2.37^{\mathrm{b}}$ & 0.015 & 48.76 & $4.17^{b}$ & $9.09^{b}$ & $10.03^{b}$ \\
\hline SF & $2.66^{\mathrm{b}}$ & 0.018 & 50.25 & $4.26^{b}$ & $9.91^{\mathrm{bc}}$ & $10.83^{b}$ \\
\hline DHA & $2.21^{\mathrm{b}}$ & 0.015 & 49.57 & $3.75^{\mathrm{a}}$ & $9.11^{\mathrm{b}}$ & $9.87^{b}$ \\
\hline SEM & 0.189 & 0.122 & 0.445 & 0.509 & 0.098 & 0.161 \\
\hline
\end{tabular}

Means with column with unique superscript differ significantly $(P<0.05)$. SEM; standard error of mean.

${ }^{1}$ TBARS; Thiobarbituric Acid Reactive Substances (mg malonaldehyde/kg of meat).

$L^{*}: 0=$ black, $100=$ white; $a^{*}: \operatorname{red}(+)$ to green $(-), b^{*}:$ yellow(+) to blue $(-)$.

injected chops in the display case for $3 \mathrm{~d}$, the panellists did give poorer scores for overall retail display and detected some color striping in the $\mathrm{CON}$ and treated chops. The objective colour score measured by the Minolta color meter showed a difference between the $1 \mathrm{~d}$ and $3 \mathrm{~d}$ chops. All the treatment groups, consistently gave higher $\mathrm{a}^{*}$ index (redness), $\mathrm{b}$ * index (yellowness), and Chroma index $\left(C=\sqrt{ } a^{2}+b^{2}\right)$ or 'vividness' as the chops aged but the effect was probably not due to the DHA oil, since the CON sample showed a higher change.

\section{Measurement of oxidation}

The degree of oxidation, as indicated by the amount of malonaldehyde generated by lipid peroxidation, was measured using the TBARS assay (Table 4). The injected loin chops and the purge juice from the meat samples were collected from the $1 \mathrm{~d}$ and $3 \mathrm{~d}$ retail display packages. On day 1 , the degree of oxidation was negligible according to the assay. On day 3 , the amount of oxidation in the purge but not the meat, was significantly higher compared to $1 \mathrm{~d}$ but not between treatment groups. Meat purge represents the free flowing juices around the meat and may have a greater chance of interacting with the atmospheric oxidation. Oxidation of meat is typically recognized as an odour or colour change, characterized as 'off odours' or a 'greying of colour' as indicated by a reduction in the Chroma. DHA injected loins had a low increase in TBARS assay values and this corresponded to a low change in colour and off odours scores according to the consumer panel (Table 4).

The DHA oil had over twice the estimated iodine index value at 271.36 than the sunflower oil at 110.43 (Table 1) and therefore the potential for lipid oxidation would be expected to be greater [33]. The sensory panellists judged the DHA and SF injected raw pork to be both worse for odour unacceptability after $3 \mathrm{~d}$, than the CON pork (Table 3). The SF treatment actually had a higher estimated iodine value in both raw and cooked pork (Table 2), compared to the DHA treatment. This higher oxidation was indicated by a non-significant higher 3d TBARS values for SF at 2.66 compared to 2.21 for DHA in the purge juice (Table 4) and also by the panellist assessment of 'off flavours' in the cooked pork (Table 5) but the CON cooked pork also rated high, which indicates that there is more to off flavours perception than just TBARS values.

Table 5 Panellist assessment on cooked loin chops for, tenderness, juiciness, saltiness, and overall palatability between injection treatments

\begin{tabular}{|c|c|c|c|c|c|c|c|c|c|c|}
\hline & $\begin{array}{l}\text { Cook time } \\
\text { (min.) }\end{array}$ & $\begin{array}{l}\text { Initial } \\
\text { tenderness }\end{array}$ & $\begin{array}{l}\text { Initial } \\
\text { juiciness }\end{array}$ & $\begin{array}{l}\text { Salt } \\
\text { intensity }\end{array}$ & $\begin{array}{l}\text { Flavour } \\
\text { desirability }\end{array}$ & $\begin{array}{l}\text { Pork } \\
\text { flavour }\end{array}$ & $\begin{array}{l}\text { Off- } \\
\text { flavours }\end{array}$ & $\begin{array}{l}\text { Sustained } \\
\text { juiciness }\end{array}$ & $\begin{array}{l}\text { Overall } \\
\text { tenderness }\end{array}$ & $\begin{array}{l}\text { Overall } \\
\text { palatability }\end{array}$ \\
\hline CON & $18.25^{a}$ & 6.91 & $5.32^{a}$ & $5.04^{a}$ & 4.71 & 4.46 & $1.14^{a}$ & 5.77 & 7.25 & 4.18 \\
\hline SF & $14.87^{b}$ & 6.73 & $5.77^{\mathrm{ab}}$ & $5.22^{a}$ & 4.75 & 4.43 & $1.16^{\mathrm{a}}$ & 6.07 & 7.31 & 4.27 \\
\hline DHA & $15.25^{b}$ & 7.11 & $6.39^{b}$ & $4.61^{b}$ & 4.62 & 4.20 & $0.75^{b}$ & 6.23 & 7.45 & 4.25 \\
\hline SEM & 0.039 & 0.037 & 0.025 & 0.096 & 0.832 & 0.595 & 0.052 & 0.265 & 0.175 & 0.926 \\
\hline
\end{tabular}

${ }^{\mathrm{ab}}$ Means with column with unique superscript differ significantly $(P<0.05)$. SEM ; standard error of mean.

Tenderness $(9=$ extremely tender to $1=$ extremely tough); juiciness $(9=$ extremely juicy to 1 extremely dry); flavour, pork flavour, palatability and sustained juiciness, overall tenderness and overall palatability $(9=$ extremely desirable to $1=$ not desirable).

Off flavour and salt intensity $(9=$ extremely intense to $1=$ none). 


\section{Sensory taste panel}

The odour and sensory evaluations were made with a eight member trained taste panel. Before the trial, the panellist were asked to evaluate the chemicals: 1-hexanal, butanoic acid, docosahexanoic acid (DHA) oil, sunflower oil (SF) and DHA or SF oil plus soy lecithin. The chemicals 1- hexanal and butanoic acid were chosen as probable breakdown products of oxidation of DHA, caused by air exposure which leads to oxygen cleavage at double bonds $[34,35]$. The 1-hexanal was described as 'stale' and 'grassy' and the butanoic acid was describes as 'rancid butter'. The DHA and DHA plus lecithin was initially odourless and nutty but was later described as fishy after exposure to air for $>1 \mathrm{~h}$. The SF and SF + lecithin was odourless then described as 'oily' or 'stale' after being exposed to air for more than $1 \mathrm{~h}$. The raw chops were allowed to reach room temperature after $1 \mathrm{~h}$ before the chops were evaluated for odours. On day 1 and 3, the vitafilm wrapped, raw loin chops were assessed for odours. The raw chops were rated as generally acceptable for overall odours on day 1 and day 3 (Table 3). There was a noticeable drop in the 'unacceptable odours' score by day 3 but this was still within the partially acceptable to neutral range and consistent between all treatments. There was no difference between the treatments and the scores were very low and unchanged for 'off' odours in the $1 \mathrm{~d}$ and $3 \mathrm{~d}$ chops.

Chops were cooked, $24 \mathrm{~h}$ after injection, and were offered to the panellists which evaluated them for palatability and sensory flavours. The amount of cooking loss (\%) was not significantly different between the CON $(22.2 \pm 2.8 \%)$, the SF $(19.9 \pm 3.6 \%)$ or the DHA $(22.4 \pm 2.2 \%)$ treatments. There was very little difference between the treatments, according to the taste panellist as well (Table 5). The injected cooked chops rated highly for scores of, initial and sustained juiciness, initial and overall tenderness, and salt intensity. Initial juiciness was scored the highest in the DHA injected chops (Table 5). Salt intensity score was reduced by the addition of DHA and should be investigated further. The addition of tripolyphosphate and water to the chops has been used in the pork industry for over a decade and in the poultry industry since 1954 [12]. It has been proposed that polyphosphate has two effects of depolymerisation of myosin filaments and weakening the binding of myosin with actin, thus promoting muscle fibre relaxing [32]. This also would permit polyphosphate treated meat to retain more water. The panellists did not score any differences in the flavour of the $1 \mathrm{~d}$ cooked chops between the treatment groups. The flavours were scored as bland, regardless of the treatments, and the overall palatability and pork flavour scored as 'slightly desirable' to 'neutral' in the trial. This is in agreement with previous sensory studies [32] which noted that the brine injected meat has only a minimal increase on saltiness scores and a less intense, pork flavour. It has been speculated that the flavour of brine injection, dilutes the carbohydrates, proteins and lipids and washes away the Maillard reactions complexes, which give meat its' roasted flavour [36]. If a panellist did mark the injected chops for 'off flavours', they scored the sample as very low and gave a description as 'stale' or 'piggy' and surprisingly, the off flavours score were higher in the untreated $\mathrm{CON}$ and SF injected cooked pork than the DHA injected cooked pork (Table 5). It has been noted that DHA triacylglycerol can impart umami and flavour and supress bitterness in certain taste panels [37].

\section{Conclusions}

The injection of pork loins with 3.1\% DHA in a tripolyphosphate brine mixture was rated to be 'desirable', by trained taste panellist. The trained taste panel also scored the cooked DHA injected pork better at surviving against 'off' flavours, than CON and SF injected pork. Increasing the lipid content $\sim 0.3 \%$ by weight in the loins may have improved the juiciness of the cooked loin, especially since the IMF of pork was $>2 \%$. DHA content was improved approximately 50 -fold to $1.16 \mathrm{mg}$ DHA/g of raw pork, which converts to $116 \mathrm{mg}$ of DHA in a typical $100 \mathrm{~g}$ serving of pork. The DHA content was further improved by cooking on a grill to $146 \mathrm{mg}$ of DHA/100 g of pork. This would meet over half the adult human recommended daily requirements for DHA omega-3 fatty acid [3]. The injection of DHA oil added to the nutritional value of the pork and will help in reducing plasma triglycerides of consumers [38].

\section{Competing interests}

The authors declare that they have no competing interest.

\section{Authors' contributions}

WJM designed and completed the overall design and statistical analysis of the experiment and was the main author of the manuscript. LG directed the sensory panel and assessment. JA performed the biochemical measurement and $\mathrm{BU}$ was responsible for the injection and preparation of marinades. MD and $\Pi$ performed the fatty acid analysis. All authors read and approved the final manuscript.

\section{Acknowledgements}

Financial support was provided by Agriculture and Agri-Food Canada. The assistance with the raising and maintenance of pigs used in the study was provided by the staff at the Lacombe Center piggery, Sheri Nelson, Michelle Hambly and Rob Hambly. Processing of the pig carcasses was provided by Chuck Pimm, Darcy Schatschneider, and Jeremy Sealock at the Lacombe abattoir. We would also like to thank, Sophie Zawadski and Glynnis Croken, who were instrumental in the preparation of the injected pork and the sensory taste panel work.

Received: 10 June 2013 Accepted: 19 November 2013

Published: 20 November 2013

\section{References}

1. Daniel CR, Cross AJ, Koebnick C, Sinha R: Trends in meat consumption in the USA. Public Health Nutr 2011, 14:575-583. 
2. Deckelbaum RJ, Akabas SR: n-3 Fatty acids and cardiovascular disease: navigating toward recommendations. Am J Clin Nutr 2006, 84:1-2.

3. Simopoulos AP, Leaf A, Salem N Jr: Essentiality of and recommended dietary intakes for omega- 6 and omega-3 fatty acids. Ann Nutr Metab 1999, 43:127-130.

4. Svennerholm L: Distribution and fatty acid composition of phosphoglycerides in normal human brain. J Lipid Res 1968, 9:570-579

5. Bradbury J: Docosahexaenoic acid (DHA): an ancient nutrient for the modern human brain. Nutrients 2011, 3:529-554.

6. Romans JR, Johnson RC, Wulf DM, Libal GW, Costello WJ: Effects of ground flaxseed in swine diets on pig performance and on physical and sensory characteristics and omega-3 fatty acid content of pork: I dietary level of flaxseed. J Anim Sci 1995, 73:1982-1986.

7. Simopoulos AP: Omega-3 fatty acids and antioxidants in edible wild plants. Biol Res 2004, 37:263-277.

8. Howe PRC, Downing JA, Grenyer BFS, Grigonis-Deane EM, Bryden WL: Tuna fishmeal as a source of DHA for n-3 PUFA enrichment of pork, chicken, and eggs. Lipids 2002, 37:1067-1076.

9. Spolaore $\mathrm{P}$, Joannis-Cassan C, Duran E, Isambert A: Commercial applications of microalgae. Journal of bioscience and bioengineering 2006, 101:87-96.

10. Stansby ME: Flavors and odors of fish oils. 1971, 48(12):820-823. Dec 1971.

11. Honkatukia M, Reese K, Preisinger R, Tuiskula-Haavisto M, Weigend S, Roito J, Maki-Tanila A, Vilkki J: Fishy taint in chicken eggs is associated with a substitution within a conserved motif of the FMO3 gene. Genomics 2005, 86:225-232.

12. Bendall JR: The swelling effect of polyphosphates on lean meat. J Sci Food Agric 1954, 5:468-475.

13. Detienne NA, Reynolds AE, Wicker L: Phosphate marination of pork loins at high and low injection pressures. J Food Qual 2003, 26:1-14.

14. Muguerza EADBJGAl: Effect of fat level and partial replacement of pork backfat with olive oil on the lipid oxidation and volatile compounds of Greek dry fermented sausages. J Food Sci 2003, 68:1531-1536.

15. Eikelenboom G, Hoving-Bolink AH, van der Wal PG: The eating quality of pork. 2. The influence of intramuscular fat. Fleischwirtschaft 1996, 76:517-518. 559-560.

16. Verbeke WVOMJWNVJBCV: Consumer perception, facts and possibilities to improve acceptability of health and sensory characteristics of pork. Meat Sci 1999, 53:77-99.

17. Baublits RT, Pohlman FW, Brown AH Jr, Johnson ZB, Proctor A, Sawyer J, Dias-Morse P, Galloway DL: Injection of conjugated linoleic acid into beef strip loins. Meat Sci 2007, 75:84-93

18. CCAC: CCAC guidelines on: the care and use of farm animals in research, teaching, and testing. 8th edition. Ottawa, ON: Canadian Council on Animal Care; 2009.

19. NRC: Nutrient requiements of swine. 10th edition. Washington DC: National Academy of Sciences; 1998

20. CMC: Food Service Meat Manual. 2nd edition. Islington, ON: Canadian Meat Council; 1988.

21. Gill CO, Jones T: The display life of retail packaged pork chops after their storage in master packs under atmospheres of $\mathrm{N}(2), \mathrm{CO}(2)$ or $\mathrm{O}(2)+\mathrm{CO}$ (2). Meat Sci 1996, 42:203-213.

22. Buys EM: Colour changes and consumer acceptability of bulk packaged pork retail cuts stored under $\mathrm{O}(2), \mathrm{CO}(2)$ and $\mathrm{N}(2)$. Meat Sci 2004, 68:641-647.

23. Sukhija PS, Palmquist DL: Rapid method for determination of total fatty acid content and composition of feedstuffs and feces. J Agric Food Chem 1988, 36:1202-1206.

24. Kramer JKG, Blais L, Fouchard RC, Melnyk RA, Kallury KMR: A rapid method for the determination of vitamin $\mathrm{E}$ forms in tissues and diet by highperformance liquid chromatography using a normal-phase diol column. Lipids 1997, 32:323-330.

25. Ham BSRBBTP: Calculating the iodine value for marine oils from fatty acid profiles. J Am Oil Chem Soc 1998, 75:1445-1446.

26. Nielsen JH, Sorensen B, Skibsted LH, Bertelsen G: Oxidation in pre-cooked minced pork as influenced by chill storage of raw muscle. Meat Sci 1997, 46:191-197.

27. AMSA: Research guidelines for cookery, sensory evaluation and instrumental measurements of fresh Meat., vol. National Livestock and Meat Board. Chicago, IL, USA: American Meat Science Association; 1995.

28. SAS: SAS user's guide: Stastics. SAS for windows, version 9.1. Cary, NC, USA: SAS Institute Inc; 2003.
29. Meadus WJ, Duff P, Uttaro B, Aalhus JL, Rolland DC, Gibson LL, Dugan MER: Production of docosahexaenoic acid (DHA) enriched bacon. J Agric Food Chem 2010, 58:465-472.

30. Stephan A, Steinhart H: Identification of character impact odorants of different soybean lecithins. J Agric Food Chem 1999, 47:2854-2859.

31. Cardenia V, Rodriguez-Estrada MT, Cumella F, Sardi L, Della Casa G, Lercker $\mathrm{G}$ : Oxidative stability of pork meat lipids as related to high-oleic sunflower oil and vitamin E diet supplementation and storage conditions. Meat Sci 2011, 88:271-279.

32. Detienne NA, Wicker L: Sodium chloride and tripolyphosphate effects on physical and quality characteristics of injected pork loins. J Food Sci 1999, 64:1042-1047.

33. Knothe G: Structure indices in FA chemistry. How relevant is the iodine value. J Am Oil Chem Soc 2002, 79:847-854.

34. Senanayake SPJN, Shahidi F: Oxidative stability of structured lipids produced from borage (Borago officinalis L.) and evening primrose (Oenothera biennis L.) oils with docosahexaenoic acid. J Am Oil Chem Soc 2002, 79:1003-1013.

35. Martin D, Antequera T, Muriel E, Perez-Palacios T, Ruiz J: Volatile compounds of fresh and dry-cured loin as affected by dietary conjugated linoleic acid and monounsaturated fatty acids. Meat Sci 2009, 81:549-556.

36. Blake A: Flavour of meat with respect to the Maillard reaction. Afinidad 1975, 32:615-618.

37. Koriyama TKTWKAH: Effects of docosahexaenoic acid content in triacylglycerol on human taste perception. J Food Sci 2002, 67:2352-2356.

38. Meadus WJ, Duff P, Rolland D, Aalhus JL, Uttaro B, Dugan MER: Feeding docosahexaenoic acid to pigs reduces blood triglycerides and induces gene expression for fat oxidation. Can J Anim Sci 2011, 91:601-612.

doi:10.1186/2049-1891-4-46

Cite this article as: Meadus et al.: Fortification of pork loins with docosahexaenoic acid (DHA) and its effect on flavour. Journal of Animal Science and Biotechnology 2013 4:46.

\section{Submit your next manuscript to BioMed Central and take full advantage of:}

- Convenient online submission

- Thorough peer review

- No space constraints or color figure charges

- Immediate publication on acceptance

- Inclusion in PubMed, CAS, Scopus and Google Scholar

- Research which is freely available for redistribution 